\section{University of New Hampshire}

Carsey School of Public Policy

\section{CARSEY RESEARCH}

National Issue Brief \#126

Summer 2017

\title{
Employment, Poverty, and Public Assistance in the Rural United States
}

Rebecca Glauber and Andrew Schaefer

$\mathrm{W}$ hen asked to describe the rural United States, people usually mention serene and sprawling farmlands, rolling hills, open spaces, and safe, idyllic communities in which to raise children. ${ }^{1}$ Although there are a lot of acres in rural America, just 6 percent of rural workers depend on agriculture. Twenty-two percent depend on manufacturing, ${ }^{2}$ and the rest work in retail, sales, health care, construction, transportation, banking, services, tourist industries, and government-similar to their counterparts in cities and suburbs.

As in cities and suburbs, rural living is also diverse. ${ }^{3}$ It takes place in chronically poor areas, like Appalachia, the Mississippi Delta, and the "Black Belt" of Alabama, and in struggling areas in the Pacific Northwest, Midwest, and Northeast where manufacturing has declined and agriculture has consolidated. It also takes place in amenity-rich areas located on the edges of urban centers-places such as the Rocky Mountains and Northern New England-into which city-dwellers have migrated in search of cleaner air, lower housing costs, and enhanced recreation.

A large body of research focuses on the divide between the rural and urban United States. These studies tell us that poverty is higher in the rural United States, incomes are lower, and job growth is nearly non-existent. ${ }^{4}$ But, as demographer Kenneth Johnson states, "Rural America' is a deceptively simple term for a remarkably diverse collection of places."

In this brief, we provide a glimpse of the economic and demographic characteristics of life in the rural United States (see Box 1 on page 3 for definitions of rural and delineations of income levels). Using data from the American Community Survey (ACS), we compare those living in low- and lower-middle-income counties (counties with average family incomes below the median for all counties in the United States) to

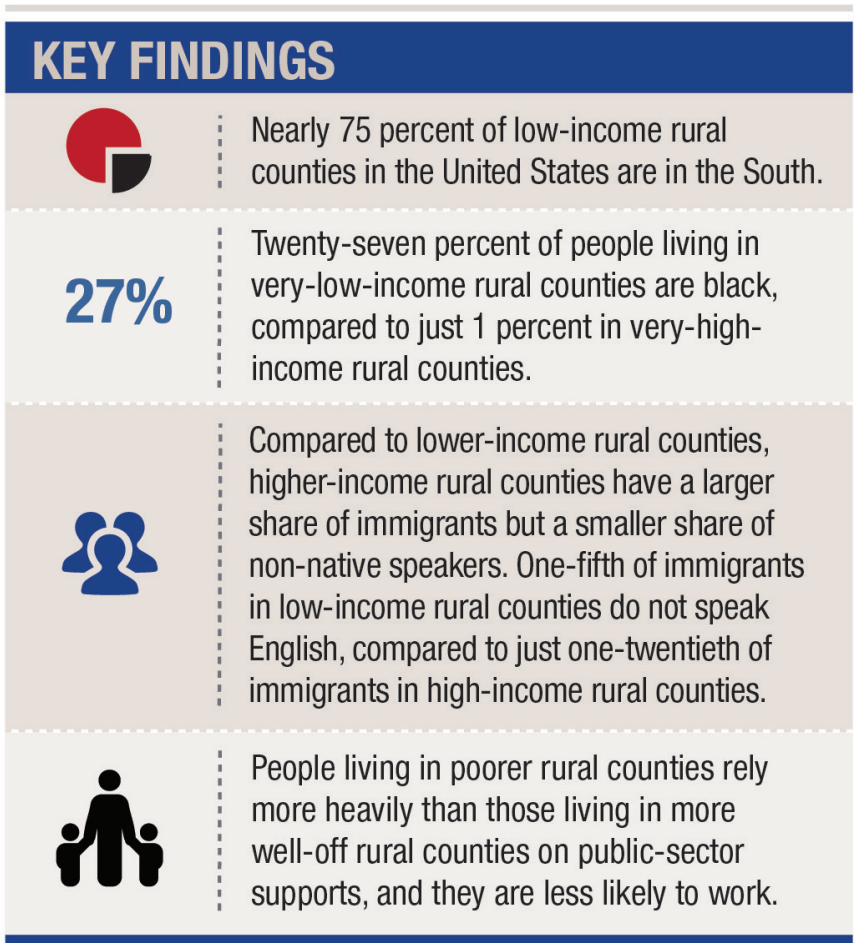

those living in upper-middle- and high-income counties. Additionally, we compare counties at the extremes, where median incomes are in the bottom and top 10 percent of the income distribution.

Low-income rural counties are clustered in the South, lower-middle- and upper-middle-income rural counties are clustered in the Midwest, and highincome rural counties are clustered in the West. Still, low-, middle-, and high-income rural counties dot nearly every corner of the United States. In Georgia, for example, over three-quarters of rural counties are low income and just 2 percent (and two counties, to be exact) are high income. In Kansas, as in most states of the Midwest, almost 80 percent of rural counties are middle income. 
Our research also reveals that differences in income levels coincide with differences in demographics. People in low-income rural areas are less educated and less likely to be employed, and those who do work are more likely to do so in manufacturing and production and less likely to do so in management, business, science, arts, recreation, and entertainment. Their incomes are also more likely to fall below the federal poverty line, and they rely more heavily on public supports.

\section{Low-Income Rural Coun- ties Are Concentrated in the South}

Figure 1 shows the distribution of income across rural U.S. counties. Those in the bottom 10 percent of the income distribution are clustered in the South. Although just 42 percent of all rural counties are located in the South, the region is home to about 75 percent of all low-income rural counties and 83 percent of all rural, very-lowincome counties, that is, those in the bottom 10 percent (Table 1 and Figure 1). In contrast, none of the very-low-income counties are in the Northeast, and fewer than 9 percent are in the West and Midwest, home to 54 percent of all rural counties.

\section{FIGURE 1. INCOME OF NONMETROPOLITAN COUNTIES, 2011-2015}

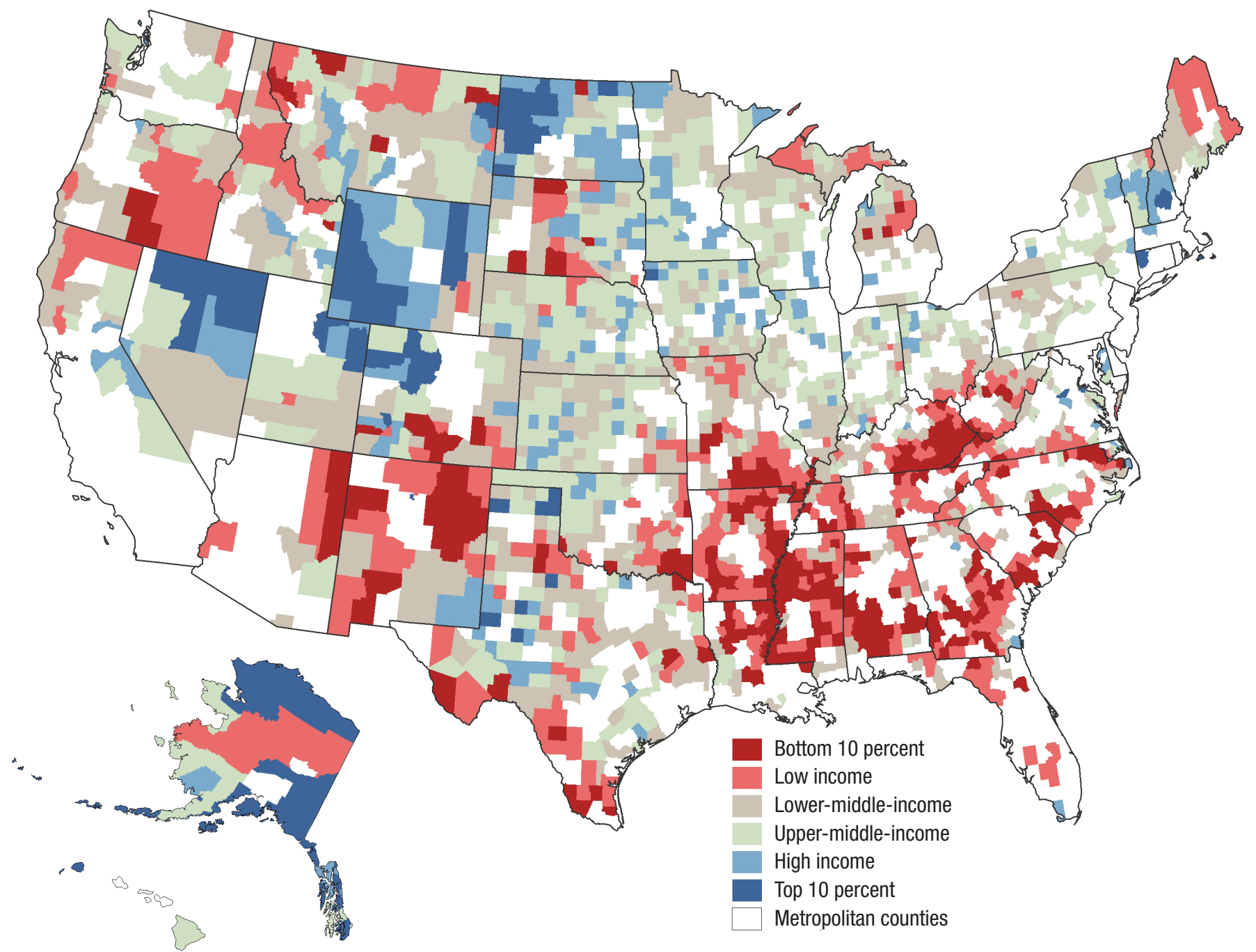




\section{TABLE 1. GEOGRAPHICAL DISTRIBUTION OF NONMETROPOLITAN COUNTIES BY INCOME OF COUNTY AND BY REGION}

\begin{tabular}{lc|c|cccc|c} 
& $\begin{array}{c}\text { ALL } \\
\text { NONMETRO } \\
\text { COUNTIES }\end{array}$ & $\begin{array}{c}\text { BOTTOM } \\
10 \%\end{array}$ & $\begin{array}{c}\text { LOW } \\
\text { INCOME }\end{array}$ & $\begin{array}{c}\text { LOWER- } \\
\text { MIDDLE- } \\
\text { INCOME }\end{array}$ & $\begin{array}{c}\text { UPPER- } \\
\text { MIDDLE- } \\
\text { INCOME }\end{array}$ & $\begin{array}{c}\text { HIGH } \\
\text { INCOME }\end{array}$ & $\begin{array}{c}\text { TOP } \\
10 \%\end{array}$ \\
\hline Northeast & $4 \%$ & $0 \%$ & $1 \%$ & $5 \%$ & $8 \%$ & $7 \%$ & $8 \%$ \\
\hline Midwest & $38 \%$ & $9 \%$ & $14 \%$ & $43 \%$ & $60 \%$ & $49 \%$ & $18 \%$ \\
South & $42 \%$ & $83 \%$ & $75 \%$ & $36 \%$ & $18 \%$ & $15 \%$ & $15 \%$ \\
\hline West & $15 \%$ & $8 \%$ & $11 \%$ & $16 \%$ & $14 \%$ & $30 \%$ & $58 \%$ \\
\hline Total number & 1,975 & 286 & 673 & 563 & 480 & 259 & 65 \\
\hline
\end{tabular}

Source: U.S. Census Bureau, American Community Survey five-year sample, 2011-2015.

\section{Box 1: Definitions}

\section{Rural and Urban}

We define counties as rural based on the Office of Management and Budget classification. Urban counties are those located within an urbanized core or any adjacent counties that have a "high degree of social and economic integration with the core." 6 All other counties are considered nonmetropolitan or "rural." Of the 3,143 counties in the United States, 1,976 are rural and 1,975 are used in this analysis.?

\section{Family Income Categories}

Bottom 10\% (very-low-income): The bottom 10 percent of counties based on median family income. In 2015, these counties had median incomes below $\$ 31,098$.

Low income: The bottom 25 percent of counties based on median family income (includes those in the bottom $10 \%$ category). These counties had incomes below $\$ 38,827$.

Lower-middle-income: The 25 percent of counties second from the bottom based on median family income. These counties had incomes between $\$ 38,827$ and $\$ 45,111$.

Upper-middle-income: The 25 percent of counties second from the top based on median family income. These counties had incomes between $\$ 45,112$ and $\$ 52,250$.

High income: The top 25 percent of counties based on median family income (includes those in the top 10\% category). These counties had incomes above $\$ 52,250$.

Top 10\% (very-high-income): The top 10 percent of counties based on median family income. These counties had incomes above $\$ 70,470$.

\section{Differences in Education and Family Structure}

As expected, those who live in lower-income rural counties have less education than those who live in higher-income rural counties (Table 2 on page 4 ). For example, 21 percent of people living in low-income rural counties have less than a high school degree, compared to just 10 percent of people living in high-income rural counties. Single parents are concentrated in lower-income rural counties, whereas married parents are concentrated in higher-income rural counties. Fifteen percent of those living in low-income counties are single parents, compared to about 12 percent in middle-income rural counties and 11 percent in highincome rural counties.

Fifteen percent of those living in low-income counties are single parents, compared to about 12 percent in middle-income rural counties and 11 percent in highincome rural counties. 


\section{TABLE 2. DEMOGRAPHIC AND ECONOMIC CHARACTERISTICS OF RURAL PEOPLE BY COUNTY INCOME LEVEL}

\begin{tabular}{|c|c|c|c|c|c|c|c|}
\hline & $\begin{array}{c}\text { ALL RURAL } \\
\text { COUNTIES }\end{array}$ & $\begin{array}{c}\text { LOW } \\
\text { INCOME }\end{array}$ & $\begin{array}{l}\text { OUNTY INC } \\
\text { LOWER- } \\
\text { MIDDLE- } \\
\text { INCOME }\end{array}$ & $\begin{array}{l}\text { OOME QUA } \\
\text { UPPER- } \\
\text { MIDDLE- } \\
\text { INCOME }\end{array}$ & $\begin{array}{l}\text { IRTILE } \\
\text { HIGH } \\
\text { INCOME }\end{array}$ & $\begin{array}{c}\text { MEDIAN } \\
\text { INCOME IN } \\
\text { BOTTOM 10\% }\end{array}$ & $\begin{array}{l}\text { MEDIAN } \\
\text { INCOME IN } \\
\text { TOP } 10 \%\end{array}$ \\
\hline \multicolumn{8}{|l|}{ Age } \\
\hline Under 18 & 23 & 23 & 22 & 23 & 23 & 23 & 23 \\
\hline 18 to 64 & 60 & 60 & 60 & 60 & 61 & 60 & 63 \\
\hline 65 and older & 17 & 17 & 18 & 17 & 16 & 16 & 13 \\
\hline \multicolumn{8}{|l|}{ Education 1} \\
\hline Less than high school & 15 & 21 & 15 & 12 & 10 & 23 & 9 \\
\hline High school degree & 36 & 37 & 37 & 36 & 31 & 37 & 28 \\
\hline Some college & 30 & 28 & 30 & 31 & 32 & 26 & 32 \\
\hline College degree & 18 & 15 & 17 & 20 & 27 & 13 & 31 \\
\hline \multicolumn{8}{|l|}{ Family structure ${ }^{2}$} \\
\hline Married with children & 26 & 23 & 25 & 27 & 29 & 22 & 32 \\
\hline Married without children & 50 & 48 & 51 & 51 & 51 & 45 & 49 \\
\hline Single with children & 13 & 15 & 13 & 12 & 11 & 17 & 11 \\
\hline Single without children & 11 & 14 & 11 & 9 & 8 & 17 & 8 \\
\hline \multicolumn{8}{|l|}{ Current labor force status } \\
\hline Employed & 53 & 46 & 52 & 57 & 62 & 44 & 66 \\
\hline Unemployed & 5 & 6 & 5 & 4 & 4 & 6 & 4 \\
\hline Not in the labor force & 42 & 48 & 43 & 39 & 34 & 50 & 30 \\
\hline \multicolumn{8}{|l|}{ Characteristics of those who worked last year 3} \\
\hline Full time, full year & 60 & 60 & 60 & 61 & 61 & 61 & 62 \\
\hline Less than full time, full year & 40 & 40 & 40 & 39 & 39 & 39 & 38 \\
\hline \multicolumn{8}{|l|}{ Occupation 3} \\
\hline Management, business, science, and arts & 29 & 28 & 29 & 30 & 33 & 27 & 34 \\
\hline Service & 19 & 20 & 19 & 18 & 18 & 20 & 18 \\
\hline Sales and office & 22 & 22 & 22 & 22 & 22 & 22 & 22 \\
\hline Natural resources, construction, and maintenance & 12 & 13 & 12 & 12 & 12 & 13 & 14 \\
\hline Production, transportation, and material moving & 17 & 18 & 18 & 18 & 15 & 19 & 11 \\
\hline \multicolumn{8}{|l|}{ Industry ${ }^{3}$} \\
\hline Agriculture, forestry, fishing and hunting, and mining industries & 6 & 6 & 5 & 6 & 7 & 6 & 9 \\
\hline Construction & 7 & 7 & 7 & 7 & 8 & 7 & 8 \\
\hline Manufacturing & 14 & 14 & 14 & 15 & 12 & 14 & 6 \\
\hline Wholesale trade & 2 & 2 & 2 & 2 & 2 & 2 & 2 \\
\hline Retail trade & 12 & 12 & 12 & 12 & 11 & 12 & 11 \\
\hline Transportation and warehousing, and utilities & 5 & 5 & 5 & 5 & 5 & 5 & 5 \\
\hline Information & 1 & 1 & 1 & 1 & 2 & 1 & 2 \\
\hline Finance and insurance, and real estate and rental and leasing & 4 & 4 & 4 & 4 & 5 & 4 & 5 \\
\hline Professional, scientific, and mgt, and administrative and waste mgt services & 6 & 6 & 5 & 6 & 7 & 6 & 9 \\
\hline Educational services, and health care and social assistance & 24 & 25 & 24 & 23 & 22 & 26 & 20 \\
\hline Arts, entertainment, and recreation, and accommodation and food services & 9 & 8 & 9 & 8 & 10 & 7 & 12 \\
\hline Other services, except public administration & 5 & 5 & 5 & 5 & 5 & 5 & 4 \\
\hline Public administration & 5 & 6 & 5 & 5 & 5 & 6 & 6 \\
\hline Poverty rate & 18 & 25 & 18 & 14 & 11 & 28 & 9 \\
\hline Percent burdened by housing costs & 27 & 28 & 27 & 26 & 28 & 29 & 28 \\
\hline Percent foreign born & 4 & 3 & 4 & 4 & 5 & 3 & 8 \\
\hline \multicolumn{8}{|l|}{ Characteristics of the foreign-born population } \\
\hline Citizen & 35 & 30 & 36 & 37 & 40 & 27 & 42 \\
\hline Noncitizen & 65 & 70 & 64 & 63 & 60 & 73 & 58 \\
\hline
\end{tabular}

Notes: 1. Age 25 years and older. 2. All families. 3. Civilians age 16 and older. Source: U.S. Census Bureau, American Community Survey five-year sample, $2011-2015$. 


\section{Low-Income Rural}

Counties Have Fewer Prime-Age Working Adults

In high-income counties, nearly three-quarters of prime-age working adults (age 25 to 54) are employed, compared to just 59 percent in low-income counties (Figure 2). These prime-age adults who are not working may be taking care of family members, discouraged from seeking a job, or unable to find a job (these data do not allow us to make these distinctions). As Table 2 shows, the share of those not in the labor force, that is, those not employed or seeking work, is much larger in low-income counties than in high-income counties-48 percent compared to 34 percent. This difference is even sharper for those living in the most and least economically advantaged rural counties. Half of all people in very-low-income rural counties are out of the labor force, compared to just 30 percent of those in veryhigh-income rural counties.

Compared to people living in very-high-income rural counties, those living in very-low-income rural counties are more likely to work in manufacturing (14 percent compared to just 6 percent). In contrast, those in high-income counties are more likely to work in the arts, entertainment, and recreation (12 percent compared to 7 percent). Over a third of all people living in high-income rural counties work in management, business, and science, compared to just over a quarter of those living in low-income rural counties.

\section{FIGURE 2. PERCENT OF NONMETRO PRIME-AGE WORKING ADULTS (25-54) WHO ARE EMPLOYED, BY INCOME OF COUNTY}

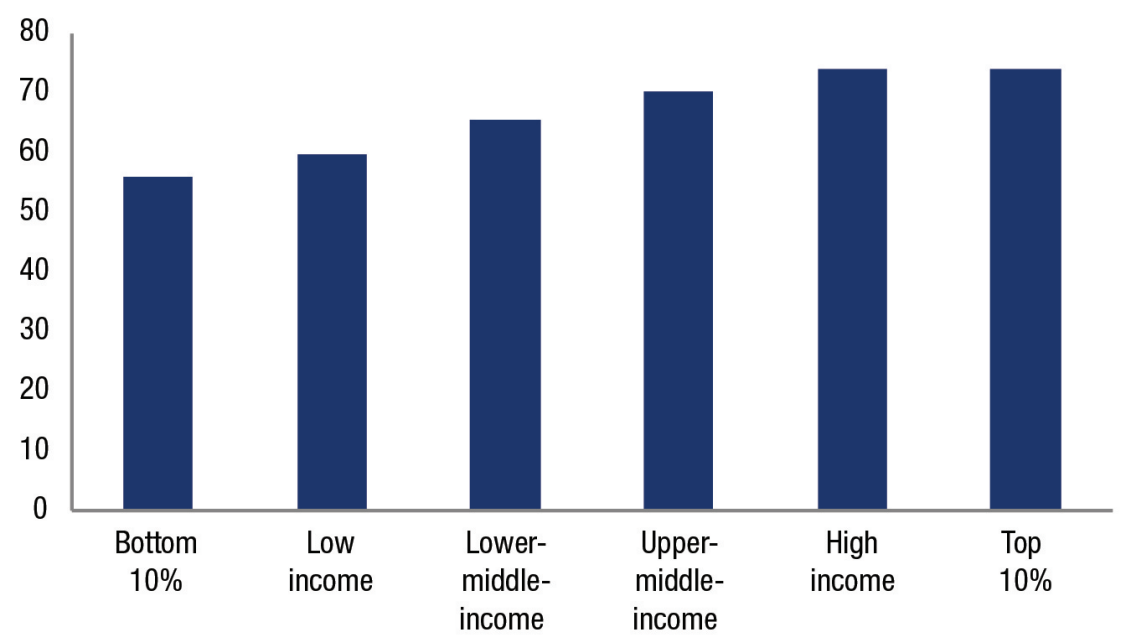

Source: U.S. Census Bureau, American Community Survey five-year sample, 2011-2015.

\section{Those Living in Poorer} Rural Counties Rely More Heavily on Public-Sector Supports

The poverty rate is higher in low-income rural counties. Onequarter of people in low-income rural areas live below the official federal poverty line, compared to just 11 percent in high-income rural areas (Table 2 ). The poverty rate in very-low-income rural counties is three times higher than it is in very-high-income rural counties (28 percent compared to 9 percent). Residents in lowerincome counties tend to rely more heavily on the social safety net.

The federal Earned Income Tax Credit (EITC) is one of the most important anti-poverty programs for low-income working Americans. ${ }^{8}$ In 2015, the average federal EITC was $\$ 3,186$ for a family with children, enough to lift 9.8 million people out of poverty. ${ }^{9}$ Those who receive the credit tend to use it to meet shortterm expenses, such as rent or car repairs. ${ }^{10}$ The credit is particularly important to rural families because they are more likely to work in low-wage jobs ${ }^{11}$ and have higher rates of child poverty. ${ }^{12}$ As Figure 3 shows, nearly a third of rural people in low-income counties and 36 percent of those in very-low-income counties claim the EITC. ${ }^{13}$ 
In 2013 , nearly 16 percent of all rural households received benefits under the Supplemental Nutrition Assistance Program (SNAP), which helps to reduce hunger and food insecurity among lowincome individuals. ${ }^{14}$ In our study, 40 percent living in very-lowincome rural counties received SNAP, compared to just 11 percent of those in very-high-income rural counties (Figure 4). Those in upper-middle-income counties were also less likely to receive SNAP than those in lower-middleincome counties (22 percent compared to 28 percent). ${ }^{15}$

Over the past decade, the share of children covered by private health insurance has declined while the share covered by public health insurance has expanded, providing access for those who would have previously gone uninsured. ${ }^{16}$ Private insurance covers most children living in highincome and upper-middle-income rural counties (Figure 5), while the majority of children in lowerincome rural counties are covered by public health insurance. Looking at the income extremes, 58 percent of children in verylow-income rural counties receive public health insurance, compared to just 23 percent in very-highincome counties.

In sum, the EITC, SNAP, and public health insurance are particularly important to those living in less affluent rural regions of the United States.

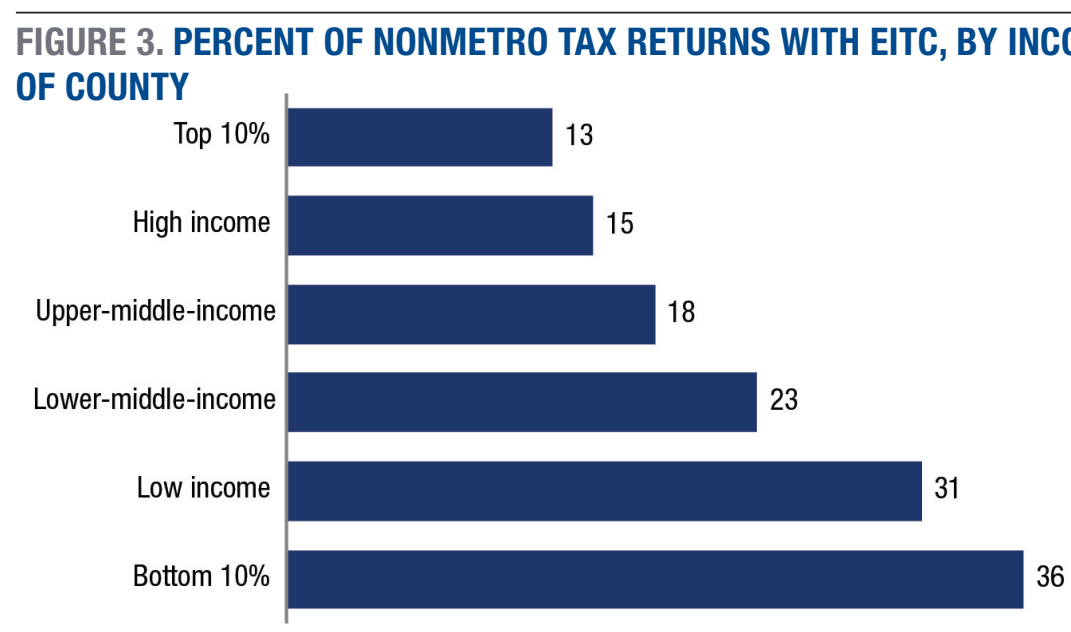

Source: U.S. Census Bureau, American Community Survey five-year sample, 2011-2015.

\section{FIGURE 4. PERCENT OF NONMETRO HOUSEHOLDS REPORTING SNAP RECEIPT, BY INCOME OF COUNTY}

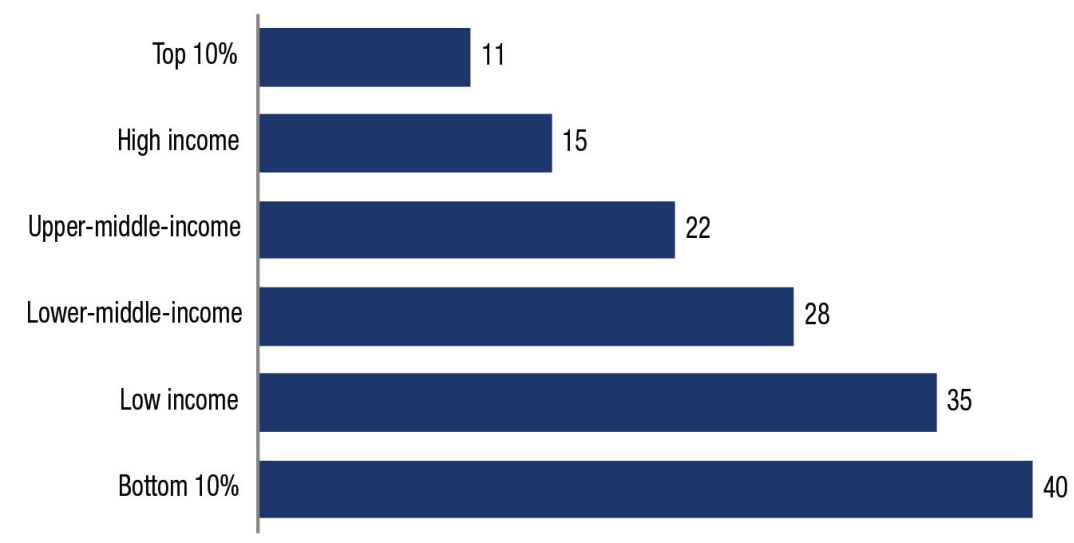

Source: U.S. Census Bureau, American Community Survey five-year sample, 2011-2015.

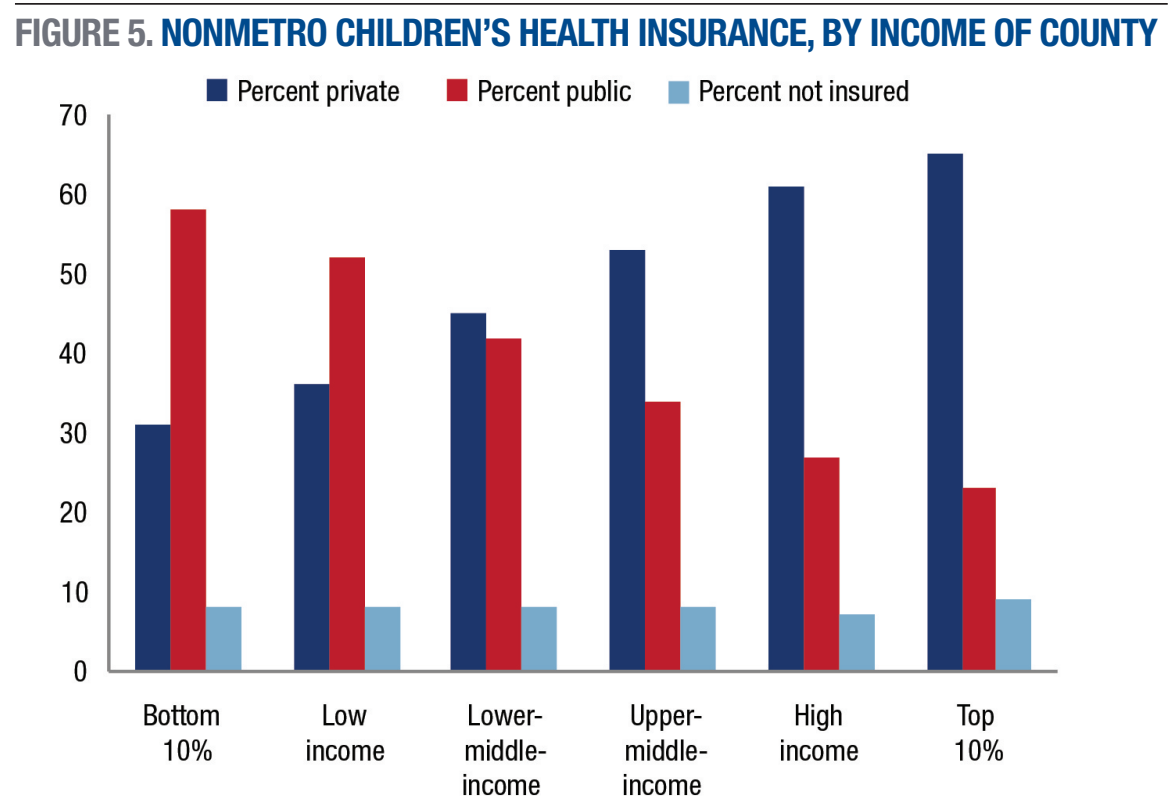

Source: U.S. Census Bureau, American Community Survey five-year sample, 2011-2015. 


\section{Racial-Ethnic Background, Citizenship, and English Language Proficiency}

Racial residential segregation persists in both the urban and rural United States. As Figures 6 and 7 show, black people are nine times more likely to be living in low-income rural counties than in high-income ones (18 percent compared to 2 percent). In contrast, in the urban United States black people are three times more likely to be living in low-income counties than in high-income ones (28 percent compared to 10 percent). It is not the case, however, that only black people are experiencing poverty: most people living in very-low-income rural counties are white. But because of institutionalized racial inequality, black people are more likely to be stuck in chronically poor rural areas.

Foreign-born individuals are more likely to live in higherincome than in lower-income rural counties. In other words, there are fewer immigrants in low-income rural areas. A recent poll found that rural residents are much more likely than urban residents to believe that immigrants are a burden to the United States, ${ }^{17}$ and one reason for this attitude may be lack of social contact: those who live in communities with more foreign-born people may be more accepting of them. As Table 2 shows, 8 percent of people living in very-highincome rural counties are foreignborn, compared to just 3 percent living in very-low-income rural

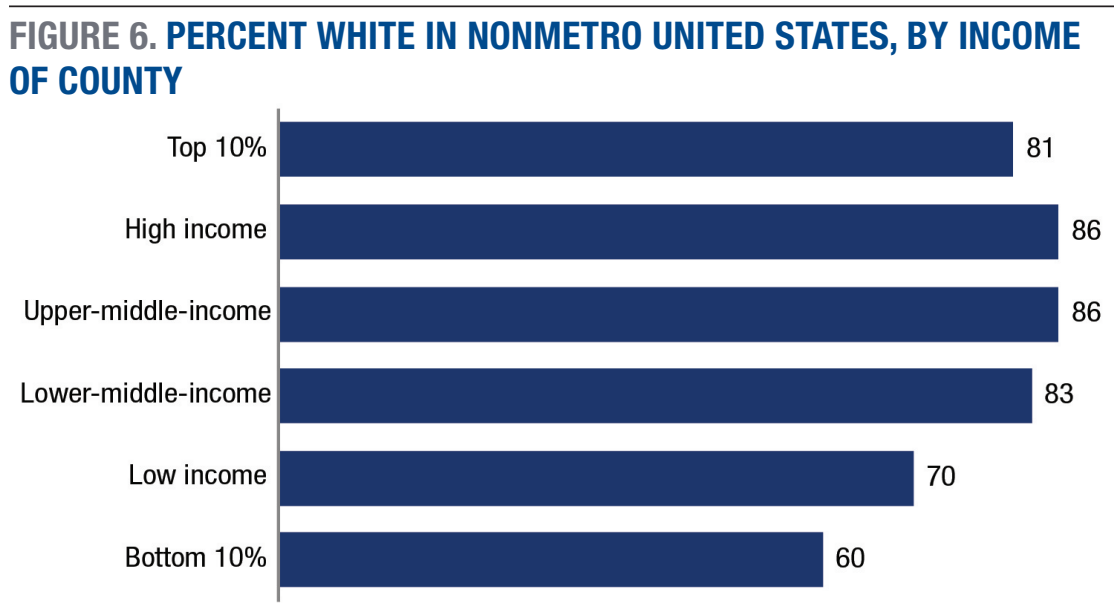

Source: U.S. Census Bureau, American Community Survey five-year sample, 2011-2015.

\section{FIGURE 7. PERCENT BLACK AND HISPANIC IN NONMETRO UNITED STATES, BY INCOME OF COUNTY}

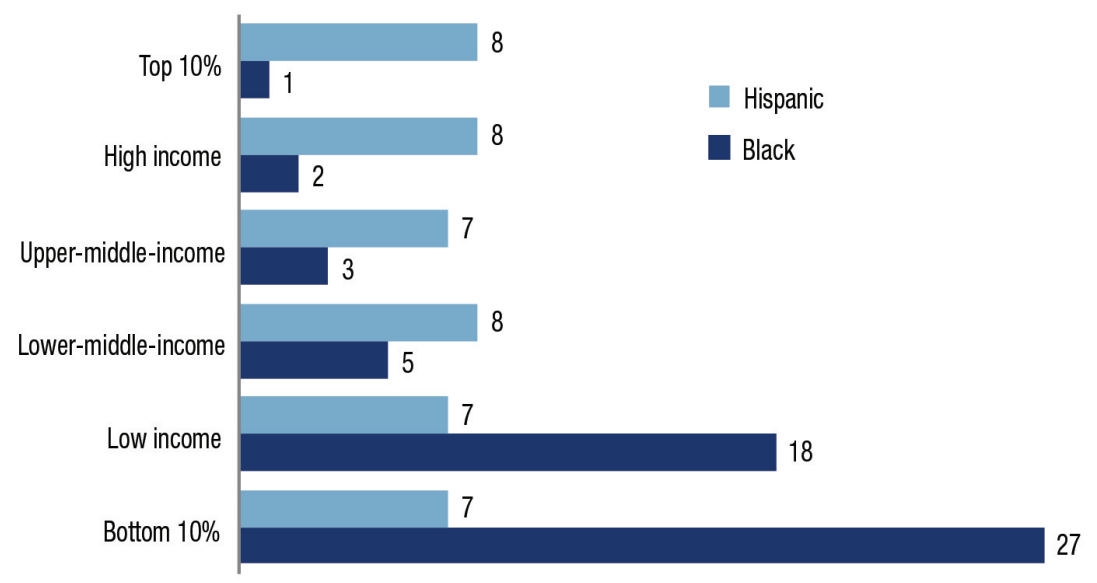

Source: U.S. Census Bureau, American Community Survey five-year sample, 2011-2015.

counties. Further, 73 percent of foreign-born people in very-lowincome rural counties are not citizens, compared to 58 percent in very-high-income rural counties, and foreign-born people in verylow-income rural counties are less likely to speak English or to speak English well (Figure 8).
Seventy-three percent of foreignborn people in very-low-income rural counties are not citizens, compared to 58 percent in veryhigh-income rural counties. 
FIGURE 8. ENGLISH LANGUAGE PROFICIENCY OF FOREIGN-BORN NONMETRO PEOPLE, BY INCOME OF COUNTY

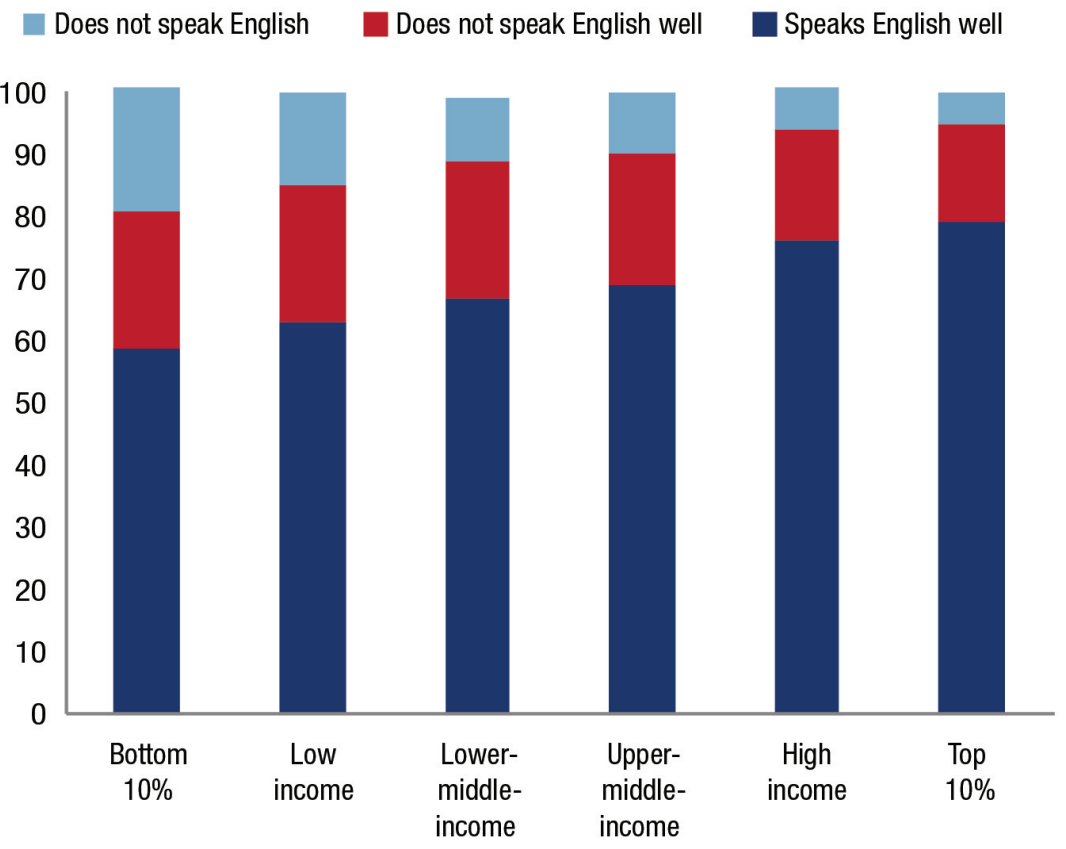

Source: U.S. Census Bureau, American Community Survey five-year sample, 2011-2015.

\section{FIGURE 9. PERCENT OF NONMETRO RESIDENTS WHO VOTED FOR THE 2016 REPUBLICAN PRESIDENTIAL CANDIDATE, BY INCOME OF COUNTY}

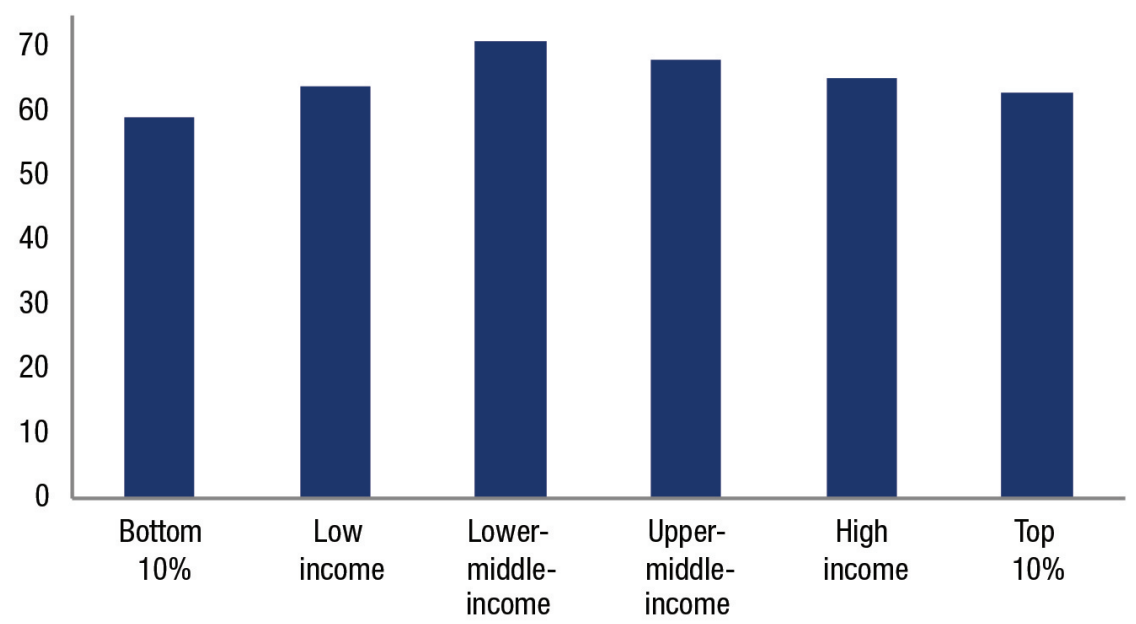

Source: U.S. Census Bureau, American Community Survey five-year sample, 2011-2015; U.S. Presidential Election Data, 2016.

\section{Rural Support for Presi- dent Trump Highest in Middle-Income Counties}

The relationship between voting and income in rural areas is complicated..$^{18}$ In a recent report, Scala and Johnson noted that "Rural America is not the undifferentiated Republican bastion depicted by commentators." ${ }^{19}$ They found that Republican candidates do best in rural areas dominated by farming, whereas Democratic candidates do best in rural counties dominated by recreation (such as ski resorts). Our research builds on this work and finds that people living in middleincome rural counties were slightly more likely to vote for the 2016 Republican presidential candidate than were either those living in low-income or high-income rural counties. Differences in voter turnout across counties could account for these differences, but nevertheless, as Figure 9 shows, 71 percent of those living in rural lower-middle-income counties and 68 percent of those living in rural upper-middle-income counties voted for President Trump, compared to just 64 and 65 percent of those in low-income and highincome counties. Although President Trump received the majority of votes in rural low-, middle-, and highincome counties, he did somewhat better in middle-income counties. 


\section{Implications for Rural Families and Children}

This brief compares affluent to less affluent rural counties. It shows that differences in the rural United States tend to fall along income lines. Compared to those living in higher-income areas, those living in lower-income rural areas are less educated and less likely to be employed, and those who are employed are more likely to work in production and manufacturing and less likely to work in management, business, sciences, the arts, and recreation. They also depend more heavily on public-sector supports. In short, our research contradicts the dominant image of a homogenous rural United States.

What does this mean for rural children and families? Nutritional assistance, public health insurance, and the EITC are most highly used among those living in low-income rural counties, and cutbacks in federal safety net programs and the proposed repeal of the Affordable Care Act (ACA) may disproportionately harm low-income people in the rural United States. The ACA led to the lowest percentage of uninsured Americans on record, ${ }^{20}$ and rural people experienced gains in coverage that were as large, if not more substantial, than Americans elsewhere. Although policy makers tend to focus on people living in the urban United States, our results show that those living in the rural United States, and particularly in low-income counties, may have even more to gain from public health insurance and other social safety-net programs.

\section{Data}

The data for this project come from the 2011-2015 five-year sample of the American Community Survey (ACS). The ACS is a yearly, 1 percent sample of all U.S. households that includes various sociodemographic indicators. The five-year sample used in this brief describes the period between January 2011 and December 2015.

\section{Endnotes}

1. "Perceptions of Rural America" (Battle Creek, MI: W.K. Kellogg Foundation, 2002), http://www.wkkf.org/resourcedirectory/resource/2002/12/perceptionsof-rural-america.

2. For more information about dependency, see U.S. Department of Agriculture, "Rural America at a Glance," 2016, https://www.ers.usda.gov/publications/ pub-details/?pubid=80893.

3. Lawrence C. Hamilton, Leslie R. Hamilton, Cynthia M. Duncan, and Chris R. Colocousis, "Place Matters: Challenges and Opportunities in Four Rural Americas (Durham, NH: Carsey Institute, 2008).

4. "Six Charts That Illustrate the Divide Between Rural and Urban America," The Conversation, 2017, https://theconversation.com/sixcharts-that-illustrate-the-dividebetween-rural-and-urban-america72934 ? sa $=$ google \&sq $=$ rural \&sr $=1$.

5. Kenneth Johnson, "Where Is 'Rural America' and What Does It Look Like?" The Conversation, 2017, https:// theconversation.com/where-is-ruralamerica-and-what-does-it-looklike-72045.
6. See the Office of Management and Budget report, "Revised Delineations of Metropolitan Statistical Areas, Micropolitan Statistical Areas, and Combined Statistical Areas, and Guidance on Uses of the Delineations of These Areas," https://www. whitehouse.gov/sites/default/files/omb/ bulletins/2013/b-13-01.pdf.

7. Loving County, Texas (population 112) does not have data for the 20112015 ACS and is, therefore, removed from analysis.

8. Marybeth J. Mattingly and Elizabeth Kneebone, "Share of Tax Filers Claiming EITC Increases Across States and Place Types Between 2007 and 2010: Recession and Policy Changes Associated with Growth," Issue Brief No. 57 (Durham, NH: Carsey Institute, 2012).

9. Center on Budget and Policy Priorities (CBPP), "Policy Basics: The Earned Income Tax Credit," 2016, http://www.cbpp.org/research/federaltax/policy-basics-the-earned-incometax-credit.

10. Alan Berube, "Using the Earned Income Tax Credit to Stimulate Local Economies," The Living Cities Census Series (Washington, DC: The Brookings Institution, 2006). See also Yannet M. Lathrop, "The Michigan EITC: A Small Investment that Makes a Big Difference" (Lansing, MI: Michigan League for Public Policy, 2013), and Caroline M. Sallee, "Economic Benefits of the Earned Income Tax Credit in Michigan" (East Lansing, MI: Anderson Economic Group, 2009).

11. William O'Hare and Elizabeth Kneebone, "EITC Is Vital for WorkingPoor Families in Rural America," Fact Sheet No. 8 (Durham, NH: Carsey Institute, 2007). 
12. Andrew Schaefer, Marybeth J. Mattingly, and Kenneth M. Johnson, "Child Poverty Higher and More Persistent in Rural America," National Issue Brief No. 97 (Durham, NH: Carsey School of Public Policy, 2016).

13. Only those with earned income are eligible for the EITC.

14. Jessica A. Carson and Paul Anskat, "Rates of SNAP Receipt Stabilize or Drop in All Regions for First Time Since Great Recession,” National Issue Brief No. 87 (Durham, NH: Carsey School of Public Policy, 2015).

15. It is beyond the scope of this brief to explore the labor force participation of SNAP recipients. However, current proposals to implement work requirements would no doubt influence the likelihood of receipt. They would also likely have a larger negative effect on poor rural residents in places where lower-on-average income limits opportunities.

16. Michael J. Staley, "More Than 95 Percent of U.S. Children Had Health Insurance in 2015: Public Coverage Drives Gains in 2015, Although Private Insurance Increased for a Second Consecutive Year," Issue Brief No. 119 (Durham, NH: Carsey School of Public Policy, 2017).

17. Maria Sacchetti and Emily Guskin, "In Rural America, Fewer Immigrants and Less Tolerance," Washington Post, June 17, 2017, https://www.washingtonpost.com/ local/in-rural-america-fewer-immigrants-and-lesstolerance/2017/06/16/7b448454-4d1d-11e7-bc1bfddbd8359dee_story.html?utm_term=.acdd4d5e0ec3.

18. Olivia Paschal, “The Rural South Defies Demographic and Political Stereotypes," https://www.facingsouth. org/2017/06/rural-south-defies-demographic-and-politicalstereotypes.

19. Dante J. Scala and Kenneth M. Johnson, "Red Rural, Blue Rural: Rural Does Not Always Equal Republican," National Fact Sheet No. 30 (Durham, NH: Carsey School of Public Policy, 2015).
20. U.S. Department of Health and Human Services, "Impact of the Affordable Care Act Coverage Expansion on Rural and Urban Populations," 2016, https://aspe.hhs.gov/pdfreport/impact-affordable-care-act-coverage-expansionrural-and-urban-populations.

\section{About the Authors \\ Rebecca Glauber is an associate professor of sociol- ogy and a faculty fellow at the Carsey School of Public Policy at the University of New Hampshire (rebecca. glauber@unh.edu).}

Andrew Schaefer is a research scientist in the Vulnerable Families program at the Carsey School of Public Policy at the University of New Hampshire (andrew.schaefer@ unh.edu).

\section{A cknow ledgments}

This brief was funded by the Annie E. Casey Foundation and anonymous donors. The authors would like to thank Michele Dillon, Michael Ettlinger, Ken Johnson, and Beth Mattingly, all at the Carsey School of Public Policy at the University of New Hampshire, for helpful comments and suggestions, Laurel Lloyd and Bianca Nicolosi at the Carsey School for layout assistance, and Patrick Watson for editorial suggestions.

\title{
TII University of New Hampshire Carsey School of Public Policy
}

The Carsey School of Public Policy at the University of New Hampshire is nationally recognized for its research, policy education, and engagement. The school takes on the pressing issues of the twenty-first century, striving for innovative, responsive, and equitable solutions.

\author{
Huddleston Hall • 73 Main Street • Durham, NH 03824 \\ (603) 862-2821 \\ TTY UsERS: DIAL 7-1-1 OR 1-800-735-2964 (RELAY N.H.)
}

carsey.unh.edu 